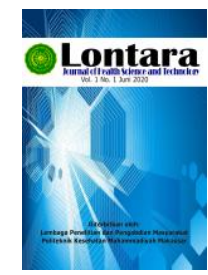

Lontara

Journal of Health Science and Technology

http://jurnal.poltekkesmu.online/lontarariset

Vol 2, No. 2, Desember 2021, pp 139-149

p-ISSN:0000-0000 dan e-ISSN: 2721-6179

DOI: https://doi.org/10.53861/lontarariset.v2i2

\title{
IDENTIFIKASI Salmonella Sp PADA SAUS CABAI PENTOLAN YANG DIPERJUALBELIKAN DI KECAMATAN MAMAJANG KOTA MAKASSAR
}

\author{
Tuty Widyanti, Muawanah, Indriany Iyonu \\ Teknologi Laboratorium Medis, Politeknik Kesehatan Muhammadiyah Makassar \\ Email: widyantituty@gmail.com
}

\section{Artikel info}

\section{Artikel history:}

Received; 03-09-2021

Revised: 22-10-2021

Accepted; 24-11-2021

Keyword:

Chili sauce, Food street,

Salmonella sp.
Kata Kunci:

Saus cabai, jajanan,

Salmonella sp.

\begin{abstract}
Sauce is a flavoring ingredient that is usually added to food. In the chili sauce processing process, it is possible that the raw materials used are not washed clean and the place used to store chili sauce is in the form of bottles or containers that do not undergo a sterilization process after use. One of the bacteria that contaminates chili sauce is Salmonella sp which can cause digestive tract disorders. The purpose of the study was to identify Salmonella sp in the pentolan chili sauce that was traded in the Mamajang sub-district, Makassar city, which was a laboratory observation using research methods, namely culture and biochemical tests. The research sample used was pentolan chili sauce that was traded in the Mamajang sub-district of Makassar city as many as 10 samples with the sampling technique of random sampling. Based on the research that has been done from 10 samples of pentolan chili sauce, positive results were obtained for Salmonella sp. It can be concluded that the pentolan chili sauce sold in the Mamajang district of Makassar city has been contaminated by Salmonella sp.
\end{abstract}

Abstrak. Saus merupakan bahan penyedap yang biasanya ditambahkan ke dalam makanan. Pada proses pengolahan saus cabai kemungkinan bahan baku yang digunakan tidak dicuci dengan bersih dan tempat yang digunakan untuk menyimpan saus cabai berupa botol atau wadah yang tidak mengalami proses sterilisasi setelah digunakan. Salah satu bakteri yang mengkontaminasi saus cabai adalah Salmonella sp yang dapat menyebabkan gangguan pada saluran pencernaan. Tujuan penelitian untuk mengidentifikasi Salmonella sp pada saus cabai pentolan yang diperjualbelikan di Kecamatan Mamajang Kota Makassar yang bersifat observasi laboratorik dengan menggunakan metode penelitian yaitu kultur dan uji biokimia. Sampel penelitian yang digunakan adalah saus cabai pentolan yang diperjualbelikan di Kecamatan Mamajang Kota Makassar sebanyak 10 sampel dengan teknik pengambilan sampel yaitu random sampling. Berdasarkan penelitian yang telah dilakukan dari 10 sampel saus cabai pentolan didapatkan hasil positif Salmonella sp. Hal ini dapat disimpulkan bahwa saus cabai pentolan yang diperjualbelikan di Kecamatan Mamajang Kota Makassar telah terkontaminasi oleh Salmonella sp. 
Coresponden author:

Email: widyantituty@gmail.com

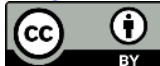

artikel dengan akses terbuka dibawah lisensi CC BY -4.0

\section{PENDAHULUAN}

Jajanan merupakan makanan siap saji atau disantap langsung di lokasi penjualan, di jalanjalan, atau tempat umum seperti kawasan pemukiman, pusat perbelanjaan, sekolah, dan pasar (Naully 2018 dalam Saleh 2020). Jajanan merupakan suatu masalah yang perlu menjadi perhatian masyarakat karena sangat rentan terhadap kontaminasi mikroba yang dapat mengganggu kesehatan (Suci, 2019). Salah satu jenis jajanan yang sering kita jumpai adalah pentolan.

Pentolan merupakan makanan ringan yang banyak ditemukan di Makassar yang digemari masyarakat baik dari kalangan dewasa hingga anak- anak. Pentolan biasanya dilengkapi dengan tahu, siomay, telur puyuh, dan pangsit. Pentolan disajikan dengan campuran saus tomat, kecap manis, dan saus cabai (Paito 2015 dalam Syaris 2018). Saus merupakan bahan penyedap yang biasanya ditambahkan ke dalam makanan, penambahan saus dapat membuat rasa masakan semakin nikmat. Selain itu adanya warna yang mencolok yang dapat meningkatkan daya tarik konsumen untuk dikonsumsi sehingga peminat pentolan dari tahun ke tahun semakin meningkat (Lutpiatina et al. 2016).

Proses pengolahan saus sangat sederhana karena penjual pentolan hanya membeli saus tomat, kecap manis, dan saus cabai di toko dan pasar dengan ukuran yang cukup besar atau dalam kilogram. Penjual pentolan biasanya juga membuat sendiri saus cabai. Pada proses pengolahan saus cabai kemungkinan bahan baku yang digunakan tidak dicuci dengan bersih dan tempat yang digunakan untuk menyimpan saus cabai berupa botol atau wadah yang tidak mengalami proses sterilisasi setelah digunakan. Hal ini akan mengurangi higienitas dan menimbulkan kontaminasi bakteri. Salah satu bakteri yang mengkontaminasi saus cabai adalah Salmonella sp (Imran, 2018).

Salmonella sp merupakan bakteri gram negatif tidak membentuk spora, fakultatif anaerob, berbentuk batang dan motil. Salmonella sp adalah bakteri yang tumbuh pada kisaran suhu $5-46^{\circ} \mathrm{C}$ pada suhu pertumbuhan optimum $35-37^{\circ} \mathrm{C}$ dan termasuk bakteri mesofilik (Supriani, 2019).

Bakteri Salmonella sp yang terkontaminasi pada makanan dapat menyebabkan gangguan kesehatan salah satunya demam tifoid dengan gejala demam tinggi, nyeri abdomen, kulit gatal, pusing dan menimbulkan bercak-bercak berwarna kemerah- merahan sehingga bakteri ini dikenal sebagai Salmonellosis yang bersifat zoonisis (Amiruddin et al. 2017). Berdasarkan penelitian sebelumnya yang dilakukan oleh Dwiyanti dan Lutpiatina (2016) didapatkan bakteri Coliform dan Staphylococcus aureus pada 8 sampel dari 10 sampel saus tomat di Banjarbaru.

Berdasarkan dari latar belakang diatas, maka peneliti tertarik melakukan penelitian untuk mengetahui Salmonella sp pada saus cabai pentolan. 
Identifikasi Salmonella Sp Pada Saus Cabai Pentolan Yang Diperjualbelikan Di Kecamatan Mamajang Kota Makassar

(Tuty Widyanti, Muawanah, Indriany Iyonu)

\section{BAHAN DAN METODE}

Lokasi pengambilan sampel dilakukan di Kecamatan Mamajang Kota Makassar. Lokasi penelitian ini. dilakukan di Laboratorium Bakteriologi Politeknik Kesehatan Muhammadiyah Makassar. Waktu penelitian ini dilakukan pada tanggal 21 April - 28 Mei 2021. Teknik pengambilan sampel dalam penelitian ini adalah Random sampling yaitu pengambilan sampel secara acak tanpa ada kriteria tertentu.

Jenis penilitian yang digunakan adalah metode observasi laboratorik bersifat deskriptif yang menggambarkan tentang identifikasi Salmonella sp pada saus cabai pentolan yang diperjualbelikan di Kecamatan Mamajang Kota Makassar. Populasi penelitian ini adalah saus pentolan yang diperjualbelikan di Kecamatan Mamajang Kota Makassar. Sampel penelitian ini adalah 10 sampel saus cabai pentolan yang diperjualbelikan di Kecamatan Mamajang Kota Makassar.

Alat-alat yang di gunakan dalam penelitian ini adalah inkubator, autoclave, lampu spritus, labu erlenmeter, rak tabung, tabung reaksi, tabung durham, objek glass, mikroskop, timbangan analitik, pipet volume, batang pengaduk, ose jarum dan ose cincin, cawan petri.

Bahan-bahan yang digunakan dalam penelitian ini adalah saus cabai pentolan, alkohol, aquadest, $\mathrm{NaCl}$ 0,9\%, Salmonella Shigella Agar (SSA) sebagai media spesifik, dan uji biokimia yang digunakan adalah Sulfur Indol Motility (SIM), Methyl Red Voges-Proskauer (MR-VP), Simon Citrate Agar (SCA), Triple Sugar Iron Agar (TSIA), gula-gula (glukosa, laktosa, maltosa), reagen metil red, kovach, alfanaftol, dan $\mathrm{KOH} 40 \%$. Untuk pewarnaan gram yang digunakan Kristal violet, gram iodium (lugol), alkohol 70\%, safranin, kapas, korek api, tisu, dan label.

Sterilisasi alat yang digunakan dan pembuatan media. Disterilkan alat yang akan digunakan kemudian dibungkus menggunakan kertas, lalu dimasukkan ke dalam autoclave dengan suhu $121^{\circ} \mathrm{C}$ selama 15 menit.

Media Pemupuk BHIB (Brain Heart Infussion Broth): Disiapkan alat dan bahan yang akan digunakan, ditimbang $1.85 \mathrm{~g}$ media BHIB ke dalam beaker glass kemudian ditambahkan aquadest sebanyak $50 \mathrm{ml}$ lalu diaduk media menggunakan batang pengaduk, kemudian dilarutkan media menggunakan hotplate hingga media larut dengan sempurna kemudian dipipet media BHIB ke dalam tabung reaksi lalu ditutup dengan kapas. Setelah itu disterilkan dalam autoclave selama 15 menit pada suhu $121^{\circ} \mathrm{C}$. Diamkan media dan simpan di dalam lemari pendingin.

Media spesifik SSA (Salmonella shigella Agar): Disiapkan alat dan bahan yang akan digunakan, ditimbang $12 \mathrm{~g}$ media SSA. Dilarutkan dengan aquades sebanyak $200 \mathrm{~mL}$ dimasukkan ke dalam Erlenmeyer, ditutup mulut erlenmeyer dengan menggunakan kapas. Dilarutkan diatas hotplate hingga media larut dengan sempurna. Disterilkan dalam autoclave selama 15 menit pada suhu $121^{\circ} \mathrm{C}$. Dikeluarkan dan dituang kedalam cawan petri 15-20 mL. Didiamkan kemudian dimasukkan ke dalam lemari pendingin.

Media TSIA (Triple Sugar Iron Agar): Disiapkan alat dan bahan yang akan digunakan, 
ditimbang 3,25 g media TSIA ke dalam beaker glass kemudian di tambahkan aquadest sebanyak 50 $\mathrm{mL}$ lalu diaduk media menggunakan batang pengaduk, kemudian dilarutkan media menggunakan hotplate hingga media larut dengan sempurna kemudian dipipet media TSIA ke dalam tabung reaksi sebanyak $5 \mathrm{~mL}$, ditutup dengan kapas. Setelah itu disterilkan media menggunakan autoclave selama 15 menit pada suhu $121^{\circ} \mathrm{C}$. Diamkan media dan dimiringkan kemudian simpan di dalam lemari pendingin.

Media SCA (Simmons Citrate Agar): Disiapkan alat dan bahan yang akan digunakan, ditimbang 4,6 g media SCA ke dalam beaker glass kemudian ditambahkan aquadest sebanyak $200 \mathrm{~mL}$ lalu diaduk media menggunakan batang pengaduk, kemudian larutkan media menggunakan hotplate hingga media larut dengan sempurna kemudian disterilkan dalam autoclave selam 15 menit pada suhu $121^{\circ} \mathrm{C}$. Kemudian dikeluarkan dan dituang ke dalam tabung. Diamkan media dan dimiringkan kemudian simpan di dalam lemari pendingin.

Media SIM (Sulfur Indol Multility): Disiapkan alat dan bahan yang akan digunakan, ditimbang 1,5 g media SIM ke dalam beaker glass kemudian di tambahkan aquadest sebanyak $50 \mathrm{~mL}$ lalu diaduk media menggunakan batang pengaduk, kemudian dilarutkan media menggunakan hotplate hingga media larut dengan sempurna kemudian dipipet media SIM ke dalam tabung reaksi lalu ditutup dengan kapas. Setelah itu disterilkan dalam autoclave selama 15 menit pada suhu $121^{\circ} \mathrm{C}$. Diamkan media dan simpan di dalam lemari pendingin.

Media MR (Methyl Red): Disiapkan alat dan bahan yang akan digunakan, kemudian ditimbang 0,85 g media MR ke dalam beaker glass kemudian ditambahkan aquadest sebanyak $50 \mathrm{~mL}$ lalu diaduk media menggunakan batang pengaduk, kemudian dilarutkan media menggunakan hotplate hingga media larut dengan sempurna kemudian dipipet media MR ke dalam tabung reaksi sebanyak 5 $\mathrm{mL}$, ditutup dengan kapas. Setelah itu sterilkan media menggunakan autoclave selama 15 menit pada suhu $121^{\circ} \mathrm{C}$. Diamkan media dan simpan di dalam lemari pendingin.

Media VP (Voges Proskauer): Disiapkan alat dan bahan yang akan digunakan, kemudian ditimbang 0,85 g media VP ke dalam beaker glass kemudian ditambahkan aquadest sebanyak $50 \mathrm{~mL}$ lalu diaduk media menggunakan batang pengaduk, kemudian dilarutkan media menggunakan hotplate hingga media larut dengan sempurna kemudian dipipet media VP ke dalam tabung reaksi sebanyak 5 $\mathrm{mL}$, ditutup dengan kapas. Setelah itu sterilkan media menggunakan autoclave selama 15 menit pada suhu $121^{\circ} \mathrm{C}$. Diamkan media dan simpan di dalam lemari pendingin

Media gula-gula: Disiapkan alat dan bahan yang akan digunakan, kemudian ditimbang masing-masing sebanyak 1,27 g lalu dimasukkan ke dalam erlenmeyer lalu ditambahkan water eton yang telah dibuat sebanyak mL setiap masing-masing gula-gula (glukosa, sukrosa, laktosa kemudian dipanaskan kurang lebih 1 menit kemudian diet ke dalam tabung dan tambahkan tabung durham lalu disterilkan menggunakan autoclave selama 1 menit ada suhu $121^{\circ} \mathrm{C}$ dan ditambahkan lautan fenol red.

Persiapan sampel: Dipisahkan saus cabai dan pentolannya ke dalam plastik kemudian sampel saus yang sudah terkumpul akan segera diperiksa di Laboratorium. 
Identifikasi Salmonella Sp Pada Saus Cabai Pentolan Yang Diperjualbelikan Di Kecamatan Mamajang Kota Makassar

(Tuty Widyanti, Muawanah, Indriany Iyonu)

Pengenceran sampel: Sampel diencerkan di labu erlenmeyer, diambil 1,15 g saus pentolan, kemudian ditambahkan $100 \mathrm{~mL} \mathrm{NaCl} \mathrm{0,9 \% ,} \mathrm{lalu} \mathrm{dihomogenkan.}$

Penanaman pada media pemuk BHIB: Disiapkan alat dan bahan yang akan digunakan panaskan ose bulat, biarkan dingin kemudian diambil suspensi kuman dengan menggunakan ose bulat lalu dimasukkan ke dalam media BHIB kemudian dianaskan lagi ose bulat dan diinkubasi media BHIB selama 2 jam dengan suhu $3^{\circ} \mathrm{C}$

Inokulasi sampel pada media SSA: Disiapkan alat dan bahan yang akan digunakan lalu diananskan ose bulat, biarkan dingin kemudian diambil susensi kuman dengan menggunakan ose bulat goreskan susensi kuman keermukaan media SSA dengan cara zigzag lalu anaskan ose kemudian di inkubasi media SSA yang telah ditanami kuman selama 24 jam ada suhu $37^{\circ} \mathrm{C}$.

Pewarnaan gram: Pertama dibersihkan kaca objek dengan alkohol. Diambil koloni sampel yang tumbuh pada media SSA dengan menggunakan ose steril, diletakkan kaca objek dan dibiarkan sampai kering diudara dan kemudian difiksasi dengan menggunakan lampu spritus. Setelah kering, diberi larutan kristal violet sebanyak 2-3 tetes dan diamkan selama 2-3 menit, lalu dicuci dengan air mengalir. Kemudian dilanjutkan pewarnaan gram dengan diteteskan dengan lugol selama 1 menit lalu dibilas dengan air mengalir dan dikeringkan. Setelah sediaan kering, dilakukan pengamatan dibawah mikroskop dengan pembesaran lensa objektif 100x. Bakteri Salmonella sp akan tampak dengan koloni berbentuk batang basil.

Inokulasi pada media TSIA: Koloni diambil pada media SSA menggunakan ose jarum yang dipanaskan lalu diambil suspensi kuman, kemudian ditusuk pada media TSIA dan dilanjutkan dengan menggores pada bagian slant secara zig-zag kemudian dipanaskan kembali ose jarum.

Inokulasi pada media SCA: Koloni diambil pada media SSA menggunakan ose jarum yang dipanaskan, kemudian diambil suspensi kuman, kemudian goreskan dan tusuk pada media SCA kemudian panaskan kembali ose jarum.

Inokulasi pada media SIM: Koloni diambil pada media SSA menggunakan ose jarum yang dipanaskan, kemudian diambil suspensi kuman, kemudian goreskan dan tusuk pada media SIM kemudian panaskan kembali ose jarum.

Inokulasi pada media MR: Koloni diambil pada media SSA menggunakan ose jarum yang dipanaskan, kemudian diambil suspensi kuman, kemudian goreskan dan tusuk pada media MR kemudian panaskan kembali ose jarum.

Inokulasi pada media VP: Koloni diambil pada media SSA menggunakan ose jarum yang dipanaskan, kemudian diambil suspensi kuman, kemudian goreskan dan tusuk kemudian panaskan kembali ose jarum.

Inokulasi sampel pada media gula-gula (glukosa, laktosa, sukrosa): Koloni diambil pada media SSA menggunakan ose bulat yang dipanaskan, kemudian diambil suspensi kuman, kemudian kocok pada media gula-gula (glukosa, sukrosa, laktosa) kemudian panaskan kembali ose bulat. 
Interpretasi hasil: pada media spesifik SSA terdapat bakteri Salmonella sp dengan ciri-ciri koloni halus, dan berbintik berwarna hitam; Pada mikroskopis pewarnaan gram bakteri Salmonella sp berbentuk basil, susunan monobasil. Berwarna merah dan sifatnya gram negative; Pada media TSIA positif jika terjadi perubahan warna dari merah ke kuning/hitam, positif gas jika bergelembung dan positif H2S jika terdapat endapan hitam pada bekas tusukan ose; Pada media SCA positif jika terjadi perubahan warna dari hijau ke biru; Pada media SIM sulfur positif jika terdapat bekas tusukan berwarna hitam, positif indol jika terbentuk cincin merah dan positif motility jika terbentuk awan pada permukaan media; Pada media MR positif ditandai dengan terbentuk cincin merah yang ditetesi methyl red; Pada media VP positif ditandai dengan terbentuk cincin ungu yang ditetesi alfanaftol; Pada media gula-gula (glukosa, sukrosa, laktosa) media glukosa positif (+) adanya gas, media laktosa (-) dan media sukrosa (-) negatif tidak adanya gas.

\section{HASIL PENELITIAN}

Berdasarkan hasil penelitian yang telah dilakukan tentang Identifikasi Salmonella sp pada saus cabai yang diperjualbelikan di Kecamatan Mamajang Kota Makassar yang dilaksanakan di Laboratorium Bakteriologi Prodi D3 Teknologi Laboratirum Medis Politeknik Kesehatan Muhammadiyah Makassar dari 10 sampel di disajikan pada tabel 1:

Tabel 1. Hasil Identifikasi Salmonella $s p$ pada saus cabai pentolan pada media SSA (Salmonella Shigella Agar)

\begin{tabular}{cclccc}
\hline NO & Sampel & $\begin{array}{c}\text { Ciri-ciri koloni } \\
\text { pada media SSA }\end{array}$ & Hasil & Keterangan \\
\hline $\mathbf{1}$ & A & Koloni halus, dan bintik berwarna hitam & + & Sesuai ciri Salmonella $s p$ \\
\hline $\mathbf{2}$ & B & Koloni halus, dan bintik berwarna hitam & + & Sesuai ciri Salmonella $s p$ \\
\hline $\mathbf{3}$ & C & Koloni halus, dan bintik berwarna hitam & + & Sesuai ciri Salmonella $s p$ \\
\hline $\mathbf{4}$ & D & Koloni halus, dan bintik berwarna hitam & + & Sesuai ciri Salmonella $s p$ \\
\hline $\mathbf{5}$ & E & Koloni halus, dan bintik berwarna hitam & + & Sesuai ciri Salmonella $s p$ \\
\hline $\mathbf{6}$ & F & Koloni halus, dan bintik berwarna hitam & + & Sesuai ciri Salmonella sp \\
\hline $\mathbf{7}$ & G & Koloni halus, dan bintik berwarna hitam & + & Sesuai ciri Salmonella sp \\
\hline $\mathbf{8}$ & H & Koloni halus, dan bintik berwarna hitam & + & Sesuai ciri Salmonella sp \\
\hline $\mathbf{9}$ & I & Koloni halus, dan bintik berwarna hitam & + & Sesuai ciri Salmonella sp \\
\hline $\mathbf{1 0}$ & J & Koloni halus, dan bintik berwarna hitam & + & Sesuai ciri Salmonella sp \\
\hline
\end{tabular}

Sumber: Data primer (2021)

Berdasarkan hasil pengamatan tabel 1 di atas dapat menunjukkan bahwa semua sampel pada saus cabai pentolan yang ditanam pada media BHIB terjadi pertumbuhan koloni dengan terjadinya kekeruhan dan pada sampel media SSA diperoleh hasil dengan ciriciri koloni halus, dan berbintik hitam. 
Identifikasi Salmonella Sp Pada Saus Cabai Pentolan Yang Diperjualbelikan Di Kecamatan Mamajang Kota Makassar

(Tuty Widyanti, Muawanah, Indriany Iyonu)

Tabel 2. Hasil Pengamatan Mikroskpoik Pada Perwarnaan Gram

\begin{tabular}{|c|c|c|c|c|c|c|}
\hline \multirow[t]{2}{*}{ NO } & \multirow[t]{2}{*}{ Sampel } & \multicolumn{3}{|c|}{ Hasil Pengamatan } & \multirow[t]{2}{*}{ Hasil } & \multirow[t]{2}{*}{ Keterangan } \\
\hline & & Bentuk Sel & Warna Sel & $\begin{array}{c}\text { Hasil } \\
\text { Pewarnaan }\end{array}$ & & \\
\hline 1 & A & Basil & $\begin{array}{l}\text { Warna } \\
\text { Merah }\end{array}$ & Gram Negatif (-) & + & Sesuai ciri Salmonella $s p$ \\
\hline 2 & B & Basil & $\begin{array}{l}\text { Warna } \\
\text { Merah }\end{array}$ & Gram Negatif (-) & + & Sesuai ciri Salmonella $s p$ \\
\hline 3 & $\mathrm{C}$ & Basil & $\begin{array}{l}\text { Warna } \\
\text { Merah }\end{array}$ & Gram Negatif (-) & + & Sesuai ciri Salmonella $s p$ \\
\hline 4 & $\mathrm{D}$ & Basil & $\begin{array}{l}\text { Warna } \\
\text { Merah }\end{array}$ & Gram Negatif (-) & + & Sesuai ciri Salmonella $s p$ \\
\hline 5 & $\mathrm{E}$ & Basil & $\begin{array}{l}\text { Warna } \\
\text { Merah }\end{array}$ & Gram Negatif (-) & + & Sesuai ciri Salmonella $s p$ \\
\hline 6 & $\mathrm{~F}$ & Basil & $\begin{array}{l}\text { Warna } \\
\text { Merah }\end{array}$ & Gram Negatif (-) & + & Sesuai ciri Salmonella $s p$ \\
\hline 7 & G & Basil & $\begin{array}{l}\text { Warna } \\
\text { Merah }\end{array}$ & Gram Negatif (-) & + & Sesuai ciri Salmonella $s p$ \\
\hline 8 & $\mathrm{H}$ & Basil & $\begin{array}{l}\text { Warna } \\
\text { Merah }\end{array}$ & Gram Negatif (-) & + & Sesuai ciri Salmonella $s p$ \\
\hline 9 & I & Basil & $\begin{array}{l}\text { Warna } \\
\text { Merah }\end{array}$ & Gram Negatif (-) & + & Sesuai ciri Salmonella $s p$ \\
\hline 10 & $\mathrm{~J}$ & Basil & $\begin{array}{l}\text { Warna } \\
\text { Merah }\end{array}$ & Gram Negatif (-) & + & Sesuai ciri Salmonella $s p$ \\
\hline
\end{tabular}

Sumber: Data primer (2021)

Berdasarkan hasil pengamatan tabel 2 menunjukkan bahwa semua sampel saus cabai pentolan pada pewarnaan gram diperoleh berbentuk basil berwarna merah dan bersifat gram negatif.

Tabel 3. Hasil Pengamatan Pada Uji Media Uji biokimia

\begin{tabular}{|c|c|c|c|c|c|c|c|c|c|c|c|c|c|c|c|}
\hline \multirow[t]{2}{*}{ Sampel } & \multicolumn{4}{|c|}{ Media TSIA } & \multirow[t]{2}{*}{ SCA } & \multicolumn{3}{|c|}{ Media SIM } & \multirow[t]{2}{*}{ MR } & \multirow[t]{2}{*}{ VP } & \multicolumn{3}{|c|}{ gula-gula } & \multirow[t]{2}{*}{ Hasil } & \multirow[t]{2}{*}{ Keterangan } \\
\hline & Lereng & Dasar & Gas & $\mathrm{H}_{2} \mathrm{~S}$ & & Sul & Ind & Moti & & & Glu & Suk & Lak & & \\
\hline $\mathbf{A}$ & Asam & Asam & - & + & + & - & - & + & + & - & + & + & + & + & $\begin{array}{c}\text { Salmonella } \\
s p\end{array}$ \\
\hline B & Asam & Asam & - & + & + & - & - & + & + & - & + & + & + & + & $\begin{array}{c}\text { Salmonella } \\
\text { sp }\end{array}$ \\
\hline $\mathbf{C}$ & Asam & Asam & + & - & + & + & + & + & + & - & + & + & + & + & $\begin{array}{c}\text { Salmonella } \\
s p\end{array}$ \\
\hline D & Asam & Asam & - & + & + & - & - & + & + & - & + & + & + & + & $\begin{array}{c}\text { Salmonella } \\
s p\end{array}$ \\
\hline $\mathbf{E}$ & Asam & Asam & + & - & + & + & - & + & + & - & + & + & + & + & $\begin{array}{c}\text { Salmonella } \\
s p\end{array}$ \\
\hline $\mathbf{F}$ & Asam & Asam & - & + & + & - & - & - & + & - & + & + & + & + & $\begin{array}{c}\text { Salmonella } \\
\text { sp }\end{array}$ \\
\hline G & Alkali & Alkali & - & - & + & + & - & - & + & - & + & + & + & + & $\begin{array}{c}\text { Salmonella } \\
s p\end{array}$ \\
\hline $\mathbf{H}$ & Alkali & Asam & - & + & + & - & + & - & + & - & + & + & + & + & $\begin{array}{c}\text { Salmonella } \\
\text { sp }\end{array}$ \\
\hline I & Alkali & Alkali & - & - & + & + & - & - & + & - & + & + & + & + & $\begin{array}{c}\text { Salmonella } \\
\text { sp }\end{array}$ \\
\hline $\mathbf{J}$ & Asam & Asam & - & - & + & + & - & + & + & - & + & + & + & + & Salmonella \\
\hline
\end{tabular}

Sumber: data primer (2021) 


\section{PEMBAHASAN}

Penelitian ini bertujuan untuk mengidentifikasi Salmonella sp pada saus cabai pentolan yang diperjualbelikan di Kecamatan Mamajang Kota Makassar dengan menggunakan metode kultur dan uji biokimia dengan prinsip untuk mengembangbiakan bakteri tertentu yang diinkubasi pada temperatur yang optimimum.

Pada penelitian ini digunakan sampel yaitu saus cabai pentolan sebanyak 10 sampel dimana sampel ini dilarutkan menggunakan $\mathrm{NaCl}$ 0,9\% sebelum dilakukan prosedur penelitian. Pembuatan larutan $\mathrm{NaCl}$ 0,9\% digunakan untuk menjaga keseimbangan ion dari mikroba. Larutan $\mathrm{NaCl}$ diperlukan untuk memberikan tekanan osmotik tertentu. Selanjutnya dimasukkan ke dalam media BHIB yang berfungsi sebagai media pemupuk untuk mengoptimalkan pertumbuhan bakteri, kemudian diinkubasi selama 24 jam pada suhu $37^{\circ} \mathrm{C}$ dengan hasil yang diperoleh yaitu terjadi kekeruhan pada 10 sampel yang menunjukkan adanya pertumbuhan bakteri.

Media SSA digunakan untuk menumbuhkan Salmonella sp karena media ini mengadung gram empedu dan brilian green sebagai bahan penghambat bakteri gram positif dan menekan pertumbuhan basil patogen non enterik. Adaun ciri ciri koloni bakteri salmonella sp pada media SSA yaitu koloni halus, berbintik hitam. Bakteri Salmonella sp mampu menghasilkan $\mathrm{H}_{2} \mathrm{~S}$ sehingga bakteri menunjukkan adanya penguraian asam amino yang mengandung sulfur sehingga didapatkan koloni berwarna hitam.

Berdasarkan hasil pengamatan secara makroskopik pada media SSA dari hasil yang didapatkan 10 sampel (sampel A - J) menunjukkan sesuai ciri-ciri dari Salmonella sp yaitu koloni halus dan berbintik hitam. Kemudian dilanjutkan pengamatan secara mikroskopik dan didapatkan hasil dari 10 sampel (sampel A-J) menunjukkan sesuai ciri-ciri dari Salmonella sp yaitu gram negatif (-) berbentuk basil. Dari hasil pengamatan makroskopik yang positif menunjukkan ciri-ciri Salmonella sp dilanjutkan ke uji biokimia.

Pada uji biokimia sampel yang positif dari media SSA diinokulasi pada beberapa media uji biokimia seperti media TSIA, SCA, SIM, MR - VP dan media gula-gula yaitu (glukosa, sukrosa, laktosa) berdasarkan penelitian yang dilakukan diperoleh hasil bahwa 10 sampel (sampel A - J) itu positif menunjukkan ciri-ciri Salmonella sp.

Adapun ciri-ciri yang didapatkan pada setiap uji biokimia antara lain Pada media TSIA. Hasil yang diperoleh untuk 10 sampel (sampel A-J) pada lereng dan dasar bersifat asam (kuning) karena bakteri mampu memfermentasikan laktosa atau sukrosa, gas negatif (-) karena tidak adanya pecahan pada media, $\mathrm{H}_{2} \mathrm{~S}$ negatif (-) karena bakteri tidak mampu mendesulfurasikan asam amino, sedangkan pada sampel G, H, I ditemukan alkali pada lereng berwarna merah karena bakteri bersifat basa ini menandakan bahwa bakteri tersebut tidak memfermentasikan sukrosa dan laktosa dan dasar berwarna kuning bersifat asam menandakan bakteri tersebut mampu memfermentasikan glukosa. Gas positif (+) pembentukan gas ini merupakan hasil dari fermentasi $\mathrm{H}_{2}$ dan $\mathrm{CO}_{2}$ dapat dilihat dari pecahnya dan terangkatnya media, $\mathrm{H}_{2} \mathrm{~S}$ positif (+) ditandai dengan adanya endapan berwarna hitam dan dapat 
Identifikasi Salmonella Sp Pada Saus Cabai Pentolan Yang Diperjualbelikan Di Kecamatan

Mamajang Kota Makassar

(Tuty Widyanti, Muawanah, Indriany Iyonu)

menguraikan asam amino yang mengandung sulfur. Sedangkan pada media SCA dari 10 sampel (sampel A-J) positif (+) terjadi perubahan warna dari warna hijau menjadi biru yang menandakan bakteri mampu tumbuh dengan mengunakan sitrat sebagai satu-satunya sumber karbon.

Pada media SIM dari 10 sampel hasil yang diperoleh untuk sulfur (+/-) hal ini disebabkan ada atau tidaknya warna hitam pada bekas tusukan, pada indol sampel $\mathrm{C}$ dan $\mathrm{H}$ didapatkan hasil positif (+) ditandai terbentuknya cincin merah dan dan pada motiliti sampel A, B, C, D, E dan J didapatkan hasil positif (+) ditandai adanya pergerakan kuman. Hal ini disebabkan bakteri menggunakan asam amino triptofan sebagai sumber karbon.

Pada media MR positif (+) karena bakteri mampu untuk mengoksidasi glukosa dengan memproduksi asam dengan konsentrasi tinggi sebagai hasil akhirnya. Pada VP negatif (-) yakni tidak terbentuk cincin ungu karena bakteri tidak menggunakan acetyl-mehylcarbino asetoin sebagai sumber permuka.

Pada media gula-gula yakni glukosa positif $(+)$, sukrosa positif (+) dan laktosa positif $(+)$ terdapat berwarna kuning karena bakteri menghasilkan gas pada tabung durham. Sehingga dapat disimpulkan dari 10 sampel (sampel A-J) yang telah diuji dinyatakan seluruh sampel mengandung Salmonella sp.

Berdasarkan hasil penelitian mulai dari pengamatan makroskopik pada media SSA proses pengamatan mikroskopik sampai pada ujibiokimia dari 10 sampel (sampel A - J) itu menunjukkan hasil positif Salmonella sp.

Adanya Salmonella sp pada 10 sampel (sampel A-J) karena proses pengolahan saus cabai pentolan kemungkinan bahan baku yang digunakan tidak dicuci dengan bersih dan tempat yang digunakan untuk menyimpan saus cabai berupa botol atau wadah yang tidak mengalami proses sterilisasi kembali setelah digunakan sehingga terkontaminasi Salmonella sp yang dapat menyebabkan gangguan pada saluran pencernaan.

Menurut Fitri et al (2013) di dalam penelitian tentang Kontaminasi Bakteri Pada Saus Tomat Mie Ayam di Pasar Condong Catur Sleman Yogyakarta menyatakan bahwa bakteri golongan coliform dapat berasal dari wadah penyimpanan yang tidak bersih, sering dibiarkan terbuka dan cara penyajian saus yang dicampur dengan air. Adapun penelitian lain yang dilakukan oleh Ratih dan Leka di dalam Medical Laboratory Technologi journal (2016) menyatakan bahwa faktor lain yang dapat menyebabkan kontaminasi bakteri adalah lalat dan bahan yang digunakan, penggunaan tangan dan lingkungan sekitar (Tampubolon R.S).

Menurut Wahab (2011), makanan yang terkontaminasi bakteri Salmonella sp dalam jumlah kecil, tidak terlalu menimbulkan perubahan dalam hal warna, bau maupun rasa dari makanan yang tercemar Salmonella sp. Jika bahan makanan mengandung Salmonella sp dalam jumlah besar maka akan terjadi perubahan warna dan bau. Semakin tinggi jumlah bakteri Salmonella sp di dalam suatu 
makanan, maka semakin besar timbulnya gejala infeksi pada orang yang mengkonsumsi makanan tersebut.

Penyakit yang ditimbulkan oleh bakteri Salmonella sp yakni keracunan darah akibat Salmonella sp ada hubungannya dengan infeksi pada tiap sistem organ. Salmonellosis biasanya menghasilkan gejala lebih ringan. Gejala akut ditandai dengan mual, muntah, kejang erut, diare, demam dan sakit kepala (SNI, 2009).

\section{KESIMPULAN DAN SARAN}

Berdasarkan hasil pemeriksaan pada identifikasi Salmonella sp pada saus cabai pentolan yang diperjualbelikan di Kecamatan Mamajang Kota Makassar yang dilakukan secara kultur dan ujibiokimia dapat disimpulkan bahwa 10 sampel saus cabai pentolan ditemukan adanya kontaminasi bakteri Salmonella sp.

Kepada masyarakat disarankan untuk lebih memperhatikan tingkat kebersihan pada tempat atau wadah saus cabai pentolan. Karena banyaknya bakteri yang dapat mengkontaminasi seperti halnya dalam penelitian ini didapatkan bakteri Salmonella sp. Bagi pedagang disarankan untuk mencuci kembali tempat atau wadah yang digunakan. Untuk peneliti selanjutnya disarankan untuk memeriksa sampel lain, tetapi menggunakan metode yang sama.

\section{UCAPAN TERIMA KASIH}

Ucapan terima kasih diberikan kepada Direktur, Ketua Prodi D3-Teknologi Laboratorium Medis (TLM) beserta seluruh civitas akademik Politeknik Kesehatan Muhammadiyah Makassar yang telah memberikan dukungan sehingga penelitian ini bisa terlaksana dengan baik.

\section{DAFTAR PUSTAKA}

Amiruddin, R, R, Darnianti \& Ismail. 2017. Isolasi Dan Identifikasi Salmonella sp Pada Ayam Bakar Di Rumah Makan Kecamatan Syiah Kuala Kota Bunda Aceh. Jurnal Jimvet. Vol. No. 3. 2017

Delila S, Indriany Y, Situmorang S. 2015. Pengambilan Keputusan Rumah Tangga Dalam Membeli Saus Sambal Botol Di Bandar Lampung. JIIA. Vol.3 No. 1. 2015

Haderiah, Sari N. 2019. Gambaran Kualitas Bakteriologis Angka Lempeng Total (ALT) Pada Pentol Goreng Di Sekolah Dasar Kecamatan Barombong Kabupaten Gowa. Jurnal Sulolipu/ Vol. 19. No. 2. 2019

Holderman. M. V, Queljoe. E.D, Rondonuwu. S. B. 2017. Identifikasi Bakteri Pada Pegangan Eskalator Di Salah Satu Pusat Perbelanjaan Di Kota Manado. Jurnal Ilmiah Sains. Vol. 17. No. 1.2017

Imran N. W. 2018. Pengaruh Penyimpanan Terhadap Mutu Saus Berbahan Dasar Cabai Merah (Capsicum Annum L.) Cabai Rawit (Capsicum Frutences L.) Yang Di Fermentasi. KTI Program Studi Ilmu Dan Teknologi Pangan Dertemen Teknologi Pertanian Fakultas Pertanian Universitas Hasanuddin Makassar. 2018 
Indrawati S, Lahming, Sukainah A. 2018. Analisis Sifat Fisiko Kimia Saus Cabai Fortifikasi Labu Siam Dan Labu Kuning. Jurnal Pendidikan Teknologi Pertanian. Vol. 4. 2018

Jawetz, Melnick, dan Adelberg's. (2005). Buku Mikrobiologi Kedokteran. Jakarta: Salemba Medika

Kurniawan, F. B li, I. T. 2018. Bakteriologi Praktikum Teknologi Laboratorium Medik. Buku Kedokteran EGG

Luptiana, Leka \& Ratih Dewi. 2016. Mutu Bakteriologis Saus Tomat Pentol. Banjar Baru. Medical Laboratory Technology Journal. 2(1). 2016 1-5

Nurdatullah. 2017. Identifikasi Bakteri Salmonella sp Pada Daging Yang Disimpan Dalam Freezer Selama Tiga Hari. KTI Akademi Analais Muhammadiyah Makassar. 2017

Saleh S.Y. 2020. Studi Literatur Identifikasi Escherchia coli Pada Siomay. KTI Akademi Analis Muhammadiyah Makassar. 2020

Saloko S, Handito D, Rahayu N, Rahman S, Dwiani A. 2019. Pengolahan Tomat Menjadi Saus Tomat. Jurnal Pendidikan Dan Pengabdian Masyarakat. Vol. 2 No. 2. 2019

Sari M. k. 2019. Analisa Kadar Pada Produk Kecap Manis Yang Dijual Di Wilayah Tambaksari Surabaya. KTI Program Studi D3 Analis Kesehatan Universitas Muhammadiyah Surabaya. 2019

Suci, E, S, T. 2019. Gambaran Perilaku Jajanan Murid Sekolah Dasar Di Jakarta. Jurnal Psikologi. $1(1) ; 29-38.2019$

Supriani. 2019. Identifikasi Salmonella sp Pada TST (Teh Susu Telur) Yang DI Perjualbelikan Di Jalan Wiliem Iskandar Medan. KTI Politeknik Kesehatan Medan Jurusan Analis Kesehatan. 2019

Suryadi Taufik. 2015. Teknik Analis DNA Dalam Mengidentifikasi Genotip Golongan Darah Pada Jenazah Kasus Forensil. Jurnal Kedokteran Syiah Kuala. Vol. 15. No. 3. 2015

Syaris S. R. 2018. Analisa Bakteri Salmonella sp Pada Saus Tomat Yang Diperdagangkan di Pasar Simpang Limun Medan. KTI Politeknik Kesehatan Kemenkes RI Jurusan Analis Kesehatan. 2018

Tampubolon R. S. 2019. Analisa Bakteri Coliform Pada Saus Tomat Jajanan dengan Metode MPN Yang Dipedagangkan Di Jalan Wiliem Iskandar Medan. KTI politeknik Kesehatan RI Medan Jurusan Analis Kesehatan. 2019

Usman N. B, Herawati N, \& Fitriani S. 2019. Mutu Saus dengan Bahan Dasar Tomat, Wortel, dan Minyak Sawit Merah. Jurnal Teknologi Pangan. Vol. 13 No. 2. 1019 